\title{
The Role of Litter Quality Feedbacks in Terrestrial Nitrogen and Phosphorus Cycling
}

\author{
Johannes M.H. Knops ${ }^{*}, 1$, David A. Wedin ${ }^{2}$ and Shahid Naeem ${ }^{3}$ \\ ${ }^{1}$ School of Biological Sciences, University of Nebraska, 348 Manter Hall, Lincoln, NE 68502, USA \\ ${ }^{2}$ School of Natural Resource Sciences, University of Nebraska, Lincoln, NE 68503, USA \\ ${ }^{3}$ Department of Ecology, Evolution and Environmental Biology, Columbia University, 1200 Amsterdam Avenue, New \\ York, NY 10027, USA
}

\begin{abstract}
Many studies in ecosystem ecology argue for strong control of litter quality over nitrogen $(\mathrm{N})$ cycling. We developed a model for temperate grasslands to test the importance of litter quality in decomposition for $\mathrm{N}$ and phosphorus (P) cycling based on the following premises. First, terrestrial $\mathrm{N}$ and $\mathrm{P}$ cycling differ fundamentally because $\mathrm{N}$ is a structural component of the soil organic matter (SOM), whereas P is not. Secondly, SOM has a much lower C:N ratio than litter inputs. Thirdly, litter decomposition follows an exponential decay with $20 \%$ of the original litter mass turning into SOM. Fourth, litter $\mathrm{N}$ concentration shows an exponential increase during decomposition, whereas $\mathrm{P}$ does not change and is released proportionally to the litter mass. Based on these premises we constructed a model which shows that $0.75 \% \mathrm{~N}$ is a critical initial litter concentration at which concentration all $\mathrm{N}$ is immobilized and no $\mathrm{N}$ is released from the litter. Thus at $0.75 \% \mathrm{~N}$ of the litter all net $\mathrm{N}$ mineralization is through SOM decomposition and not through litter decomposition. Phosphorus, in contrast, is primarily released in the early stages of litter decomposition. Empirical tests of these model predictions support the applicability of the model to temperate grassland ecosystems. This model predicts that $\mathrm{N}$ mineralization from SOM is much more important than mineralization from litter and that plant litter quality differences alone cannot explain ecosystem $\mathrm{N}$ cycling patterns. Phosphorus, in contrast, does cycle largely through litter decomposition, and plant litter quality differences are the dominant factor in determining ecosystem P cycling feedbacks.
\end{abstract}

Keywords: Decomposition, immobilization, mineralization, nitrogen cycling, phosphorus cycling, soil organic matter.

\section{INTRODUCTION}

Several key papers in the early 1990's emphasized the role of plant litter quality in determining the rate of nutrient cycling in terrestrial ecosystems (Wedin and Tilman, 1990, Hobbie, 1992). These "litter quality feedback" papers dealt primarily with $\mathrm{N}$, as has much of the subsequent literature. Considering that the importance of $\mathrm{P}$ limitation had been demonstrated in many tropical ecosystems (Vitousek, 1984, Vitousek and Howarth, 1991) and that evidence for a strong role of $\mathrm{P}$ limitation in $\mathrm{N}$-saturated temperate ecosystems is increasing (Aerts et al., 1992), it is surprising that litter quality feedback papers often did not include P cycling in their analyses.

To answer the question 'What role do litter quality feedbacks play in nutrient cycling?' therefore requires considering both $\mathrm{N}$ and $\mathrm{P}$ cycling, not just one or the other. We employ this pluralistic approach here by developing a model that explicitly includes $\mathrm{N}$ and P. Our study addresses this question by separating it into two parts: 1) What proportion of the $\mathrm{N}$ and $\mathrm{P}$ found in fresh plant litter is released during the litter phase of decomposition?; and 2) How sensitive is the $\mathrm{N}$ and $\mathrm{P}$ release rate of litter to plant

*Address correspondence to this author at the School of Biological Science, University of Nebraska, USA; Tel: (402)310-3904; Fax: (402)472-2083; E-mail: jknops2@unl.edu

Handling Editor: Helena Freitas litter chemistry (i.e. $\% \mathrm{~N}$ and $\% \mathrm{P}$ ) versus SOM characteristics? In particular, we will examine the impact of varying the proportion of plant litter stabilized as SOM and varying the $\mathrm{C}: \mathrm{N}: \mathrm{P}$ ratios of SOM. We stress that our focus is on $\mathrm{N}$ and $\mathrm{P}$ dynamics during plant litter decomposition. Thus, our model is not a complete ecosystem nutrient cycling model and does not estimate net $\mathrm{N}$ mineralization, which would include $\mathrm{N}$ mineralization from SOM, or total $\mathrm{P}$ availability, which would include the release of mineralassociated $\mathrm{P}$.

\section{TERRESTRIAL NUTRIENT CYCLING}

Nitrogen limitation in net primary productivity is widespread in terrestrial ecosystems (Vitousek and Howarth, 1991), therefore $\mathrm{N}$ cycling is a fundamentally important process in ecosystems. Proximate reasons for this $\mathrm{N}$ limitation is the loss of $\mathrm{N}$ because of the high mobility of nitrate, which is the most abundant mineral form of $\mathrm{N}$ in many well drained terrestrial ecosystems (Schlesinger, 1997). In addition, only a few, often rare, organisms can fix $\mathrm{N}$ (Vitousek et al., 2000) and these organisms are often constrained by factors such as P limitation (Smith, 1992, Crews, 1993), and selective herbivory (Ritchie and Tilman, 1995, Knops et al., 2000). Nitrogen is also thought to be the primary element limiting terrestrial ecosystem processes because the largest $\mathrm{N}$ pool is the atmospheric $\mathrm{N}_{2}$ pool, the least reactive form of N. Furthermore, SOM is the dominant 
$\mathrm{N}$ pool in terrestrial ecosystems (Schlesinger, 1997). Forest ecosystems, for instance have $46 \%$ of their organic matter in roots and aboveground live biomass, whereas $54 \%$ of the organic matter is present in the litter and the SOM. In contrast, $91 \%$ of the entire ecosystem $\mathrm{N}$ pool is present in SOM and litter (Fig. 1), and for grasslands up to $98 \%$ of the

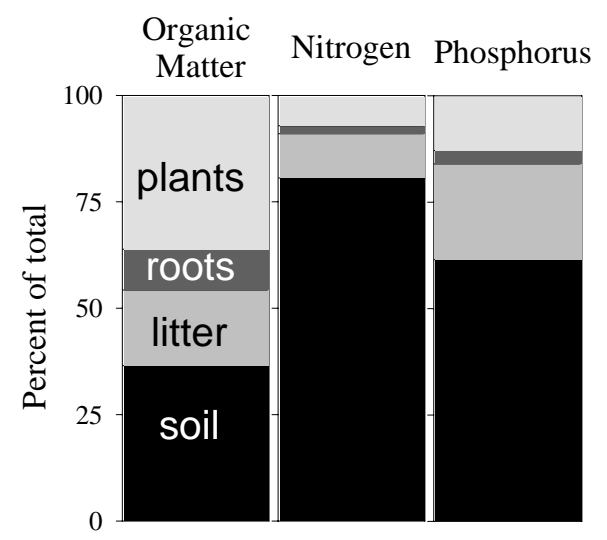

Fig. (1). Forest ecosystem organic matter, nitrogen and phosphorus pool components. Data are from (Cole and Rapp, 1981) and are the average of 16 sites, mostly boreal and northern temperate forests. The average amount of organic matter is $48.6 \mathrm{~kg} / \mathrm{m}^{2}$ (range 13.0 to 218.6 ), with $54 \%$ in the litter and soil (range $39 \%$ to $81 \%$ ), nitrogen is $618 \mathrm{~g} / \mathrm{m}^{2}$ (range 131 to 1096), with $91 \%$ in the litter and soil (range $87-96 \%$ ) and phosphorus is $124 \mathrm{~g} / \mathrm{m}^{2}$ (range 12 to 328 ) with $80 \%$ in the litter and soil organic matter (range 44-99\%).

$\mathrm{N}$ is present in SOM (Knops and Bradley, 2009). This terrestrial $\mathrm{N}$ is largely in relatively stable organic components with turnover times of thousands of years (Jenkinson and Rayner, 1977, Post et al., 1985). Phosphorus, in contrast, has a large fraction in the soil is in inorganic forms, especially occluded forms of $\mathrm{P}$ (Cross and
Schlesinger, 1995). This occluded $\mathrm{P}$ is extremely insoluble, stable over long periods and not available for plant uptake (Walker and Syers, 1976).

Terrestrial nutrient cycling is structured by autotrophic plants, which incorporate minerals into organic compounds. After senescence or death, litter enters the decomposition process in which organic matter is broken down and nutrients are released in an inorganic form, i.e. mineralized (Fig. 2). This plant-litter-soil cycle is considered the core of ecosystem cycling which dominates the dynamics of ecosystem N cycling (Likens et al., 1977, Pastor and Bockheim, 1984, Stinner et al., 1984, Waring and Schlesinger, 1985, Vitousek and Walker, 1989, Attiwill and Adams, 1993, Knops et al., 1996, Schlesinger, 1997). In most unpolluted, natural terrestrial ecosystems, this internal ecosystem nutrient recycling exceeds the inputs-outputs fluxes by a large amount, especially for $\mathrm{N}$ and $\mathrm{P}$ (Schlesinger, 1997). Decomposers and plants compete for the released $\mathrm{N}$ minerals as both are frequently limited by $\mathrm{N}$ (Zak et al., 1990, Harte and Kinzig, 1993) and as such the release of $\mathrm{N}$ in the decomposition process can both control decomposition, plant productivity and litter production. Thus, nutrient cycling has the potential to lead to positive and negative feedbacks. However, nutrients can be mineralized and released from the organic matter at two points, directly from the litter (A in Fig. 2), or after the litter has been transformed into SOM (B in Fig. 2). If nutrients are mineralized during litter decomposition, the timescale of the release is relatively rapid and the potential for positive or negative feedbacks large. However, if nutrients are primarily mineralized during SOM decomposition, the timescale of any potential feedback is much longer because of the long time lag between the production of litter and the actual release of nutrients. Herbivory can be locally important by affecting the openness of the $\mathrm{N}$ cycling through selective consumption of $\mathrm{N}$ fixers (Ritchie and Tilman, 1995) and by

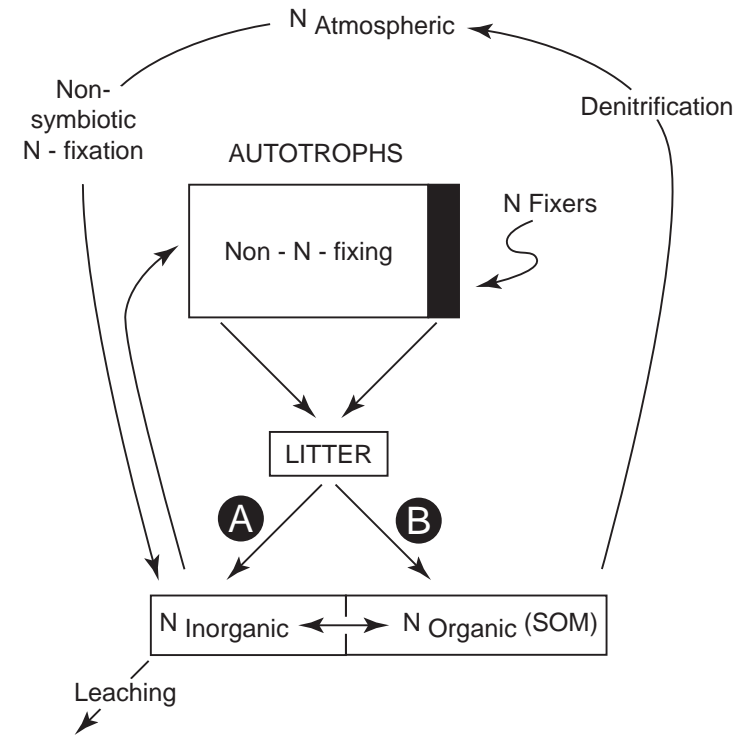

N CYCLING

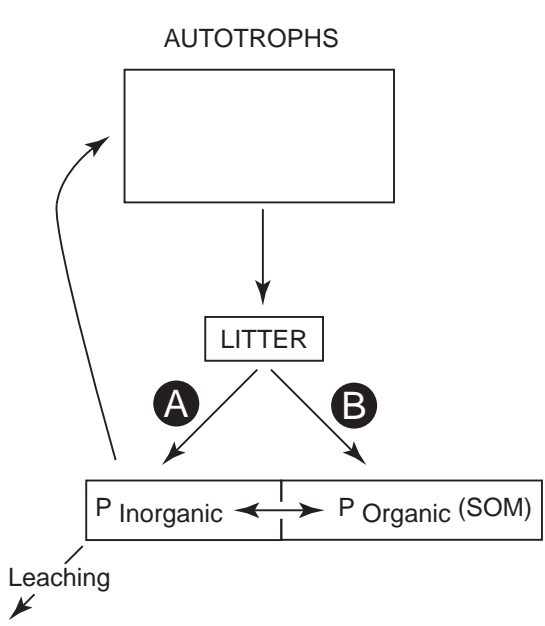

P CYCLING

Fig. (2). Nitrogen and phosphorus cycling. Nutrients cycle through decomposition either through pathway A or B. If A, then nutrients are mineralized during litter decomposition at biological meaningful time scales. If B, then nutrient are incorporated into soil organic matter and released at low rates, as soil organic matter is mineralized. This paper addresses this issue. 
speeding up the return of nutrients to the soil pool (Hollinger, 1986, Frank et al., 1994). However in most terrestrial ecosystems herbivory does not fundamentally change the cycle between plants and decomposers (de Mazancourt and Loreau, 2000).

Soil organic $\mathrm{N}$ occurs for a large part in closed ring heterocyclic compounds (Schulten and Schnitzer, 1998). Thus, a large part of soil organic $\mathrm{N}$ is a structural component of SOM (McGill and Cole, 1981). This is in contrast with P, which is not a structural component of SOM. Rather P is present in the form of ester linkages that can be split by extracellular enzymes (McGill and Cole, 1981). Old SOM (i.e. decomposed over a long time period without the continuous input of new litter), regardless of the climate in which it is formed (Sowden et al., 1977), generally has a C:N ratio of 12 or lower (Waksman, 1924), which is much lower than ratios of 50-200 for litter (Fog, 1988, Brady and Weil, 1999, Coyne, 1999). The low C:N ratio of SOM may be a result of a similar ratio within soil microbes (Waksman, 1924), or alternatively, $N$ may contribute to the structural integrity of the SOM. It is clear, regardless of the mechanisms, that a low $\mathrm{C}: \mathrm{N}$ ratio is a fundamental character of SOM (we exclude organic soils such as peats formed under anaerobic conditions from our discussion). Jobbagy \& Jackson (2001) found an average C:N ratio within the top meter of soils of 8.3 for aridisols, 10.2 for mollisols and 12.9 for ultisols and a decrease in $\mathrm{C}: \mathrm{N}$ ratio with soil depth. However, note that this includes the entire SOM, e.g. old and new, and there might be differences among soil types or climatic regions. We analyzed a 1 meter deep paleosol formed under a $\mathrm{C}_{4}$ grasslands vegetation from the Sandhills of Nebraska to verify the $\mathrm{C}: \mathrm{N}$ ratio of old SOM. This paleosoil has a $\mathrm{C}^{14}$ age of 1800 years and was buried 830 years ago (Goble et al., 2004). The C: $\mathrm{N}$ of this paleosoil was $8.2(\mathrm{SE} 0.1, \mathrm{n}=5)$, whereas the current surface soil had a $\mathrm{C}: \mathrm{N}$ ratio of 12.2 (SE $0.1, n=5$ ). In our decomposition model, we initially assume that old SOM has a $\mathrm{C}: \mathrm{N}$ ratio of 12 , although we test the behavior of the model across a broad range of $\mathrm{C}: \mathrm{N}$ ratios $(6-24)$.

Soil organic matter is formed from plant litter, and the transformation of litter into SOM can be viewed as a continuum following an exponential decay curve (Melillo et al., 1989). A single exponential decay function (i.e. treating litter as one homogeneous pool) has been used for a large variety of litter types ( $\mathrm{g} g r e n$ and Bosatta, 1996, Berendse et al., 1987, Hobbie, 1996, Wadman and de Haan, 1996). More complex exponential decay models explicitly consider the dynamics of a highly labile, initially leached organic pool and a recalcitrant, relatively stable pool. Various long-term decomposition studies find that about $20 \%$ of decomposing plant litter is resistant to decomposition and is stabilized as SOM (Melillo et al., 1989, Berg et al., 1982, Berg and Ågren, 1984). The majority of decomposition studies, however, use litterbags in which long-term measurements are problematic because of litter fragmentation, loss and microbial transformations (Wedin et al., 1995). For our litter decomposition model, we assume that mass loss follows a single exponential decay curve up to the point of $80 \%$ mass loss, and that the remaining $20 \%$ is transformed either directly or indirectly through microbes into SOM.

\section{N AND P DYNAMICS DURING LITTER DECOMPOSITION: EMPIRICAL PATTERNS FROM TWO STUDIES}

Combining the exponential decay and the $20 \%$ litter incorporation into SOM with the observed $\mathrm{C}: \mathrm{N}$ ratio of SOM allows us to plot mass loss in relation to the $\mathrm{N}$ concentration of litter. For instance, using data from a study by Knops et al (1996), epiphytic lichens and deciduous oak leaves show an exponential mass loss over a four-year period of decomposition. We can also plot mass loss in relation to tissue $\mathrm{N}$ and $\mathrm{P}$ concentration (Fig. 3) and include the endpoint of decomposition (e.g. the SOM as $20 \%$ mass remaining with $3.75 \% \mathrm{~N}, 45 \% \mathrm{C}, \mathrm{C}: \mathrm{N}$ ratio of 12 , represented by the star in Fig. 3 and 4). Litter shows an exponential decline of mass loss with an increase in $\mathrm{N}$ concentration (Fig. 3), whereas $\mathrm{P}$ concentration converges to $0.11 \%$ (Fig. 3). Thus, the basic pattern is that as litter decomposes, $\mathrm{C}$ is lost faster than $\mathrm{N}$. This leads to an increase in the $\mathrm{N}$ concentration present in the litter, and the basic retention of the $\mathrm{N}$ within the litter leads to a $\mathrm{C}: \mathrm{N}$ ratio of 12 in SOM (or $3.75 \% \mathrm{~N}$ ). Phosphorus, in contrast, behaves differently and does not show a consistent increase during decomposition (Fig. 3). This is supported by studies examining SOM that show that soil organic $\mathrm{P}$ is not a structural component of SOM (Schulten and Schnitzer, 1998) and can be rapidly released from decomposing litter (Eason and Newman, 1990). Note that using the $\mathrm{C}$ to $\mathrm{P}$ ratio of soil is problematic, because in addition to organic $\mathrm{P}$, soil includes various inorganic and occluded $\mathrm{P}$ fractions which make up the majority of soil P (Cross and Schlesinger, 1995).

Wedin et al. (1995) examined above- and belowground decomposition of four common prairie grasses that strongly differ in $\mathrm{N}$ use efficiency and impact ecosystem $\mathrm{N}$ cycling (Tilman and Wedin, 1991, Wedin and Pastor, 1993, Knops et al., 2002). They found that over a 3.7 year period 50 to $77 \%$ of the litter mass was lost during decomposition. Initial $\mathrm{N}$ concentrations varied from 0.37 to $1.66 \%$. Litter of both above- and belowground tissues declined exponentially with increasing $\mathrm{N}$ content as decomposition progressed (Fig. 4). Our hypothesized endpoint of litter decomposition is consistent with a trajectory of increasing $\mathrm{N}$ content. However, note that these data do not cover the entire course of litter decomposition and estimates become increasingly imprecise with time. Both above- and belowground litter of Schizachyrium scoparium are associated with strong immobilization of $\mathrm{N}$, which is consistent with the initial $\mathrm{N}$ content of 0.37 and $0.50 \%$ (Fig. 5). Belowground litter of Agrostis scabra shows the largest mineralization, consistent with the highest initial $\mathrm{N}$ percentage of $1.66 \%$. Other species and tissues are intermediate and show small rates of mineralization, consistent with their initial $\mathrm{N}$ concentration. The phosphorus concentration varied from 0.067 to $0.32 \%$ over a 3.7 year period (Fig. 4). Seven of the eight litter types showed a decrease over time if the initial litter $\mathrm{P}$ was above $0.1 \%$ and an increase if the initial concentration was below $0.1 \%$. However, the trajectory of $\mathrm{P}$ change in the litter does vary among the species, with a rapid change of litter $\mathrm{P}$ content for Poa, Agrostis aboveground and Schizachyrium belowground. Agropyron shows a more gradual change over 


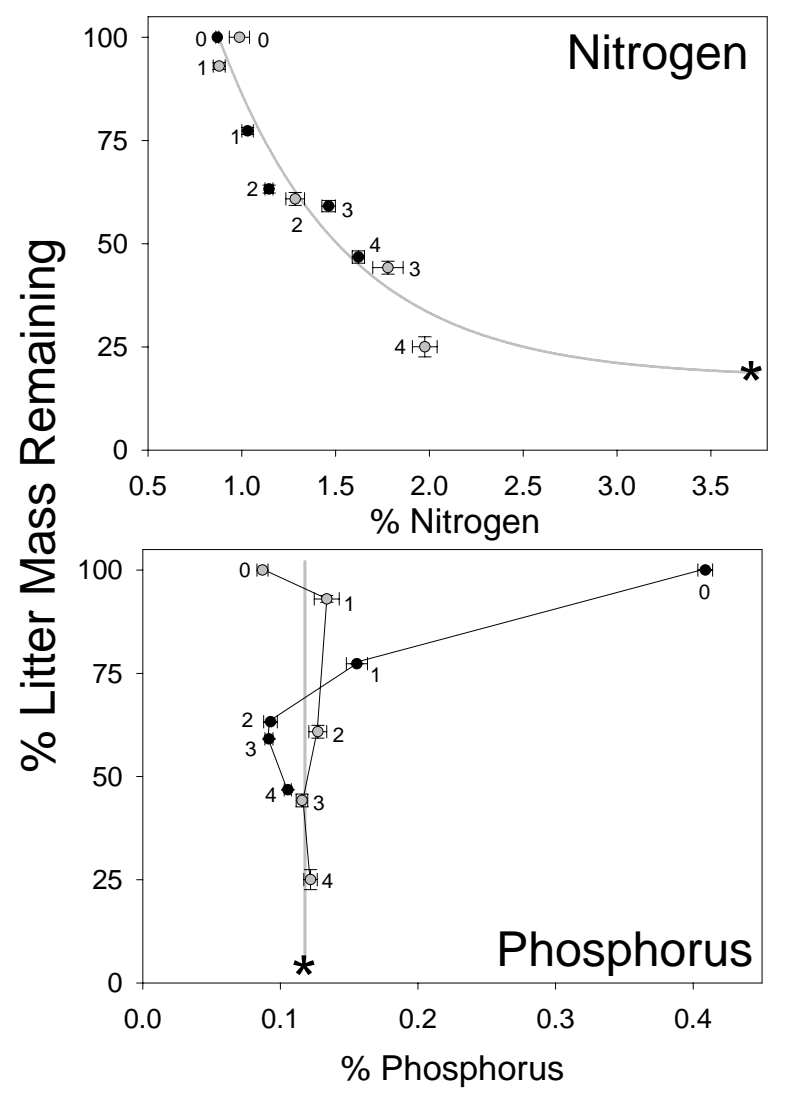

Fig. (3). Litter mass loss versus litter percent nitrogen, respectively litter percent phosphorus during decomposition. Data consists of measurements of oak leaves (solid circles, $\mathrm{n}=20$, Quercus douglasii, a deciduous oak) and an epiphytic lichen (gray circles, $\mathrm{n}=10$, Ramalina menziesii) during four years of decomposition. Data points are the means and $1 \mathrm{SE}$ by year. The number indicates the number of years since the start of decomposition. * denotes the $\%$ nitrogen and \% phosphorus in soil organic matter. All data methods can be found in Knops et al. $(1994,1996)$. The curves are fitted through all datapoints and show an exponential decay following $\mathrm{y}=17.6+301.4 * \mathrm{e}^{-1.48 \mathrm{x}}, \mathrm{F}_{9}=72.2, \mathrm{P}<0.0001, \mathrm{R}^{2}=0.94$ for the relationship between mass loss and nitrogen.

time. Agrostis belowground shows no real change, and Schizachyrium aboveground shows a rapid decrease followed by an increase in litter P concentration (Fig. 4). The amount of $\mathrm{N}$ remaining after one year in the decomposing litter was on average $70 \%$ (range $45-100$ ) and $88 \%$ (range $38-172$ ) of the initial value for the oldest litter, whereas $P$ remaining was on average $40 \%$ (range $13-100$ ) after 1 year and $29 \%$ (range $10-92$ ) for the oldest litter (Fig. 5). Thus, initial $\mathrm{P}$ release varies more among the litter types than $\mathrm{N}$, and is on average higher than $\mathrm{N}$ release. $\mathrm{P}$ release is continuous over time whereas $\mathrm{N}$ shows either immobilization or mineralization depending on the initial litter quality.

Nitrogen and $\mathrm{P}$ behaved strikingly differently. However across systems $\mathrm{N}$ showed the same pattern, as does $\mathrm{P}$ (Figs. 3 and 4). Nitrogen in both systems increased during decomposition towards a $\mathrm{C}: \mathrm{N}$ of 12 or $3.75 \% \mathrm{~N}$ when $20 \%$ of the litter remains. Phosphorus converged towards $0.12 \% \mathrm{P}$ much earlier during decomposition (the points represented by the star in the figures).

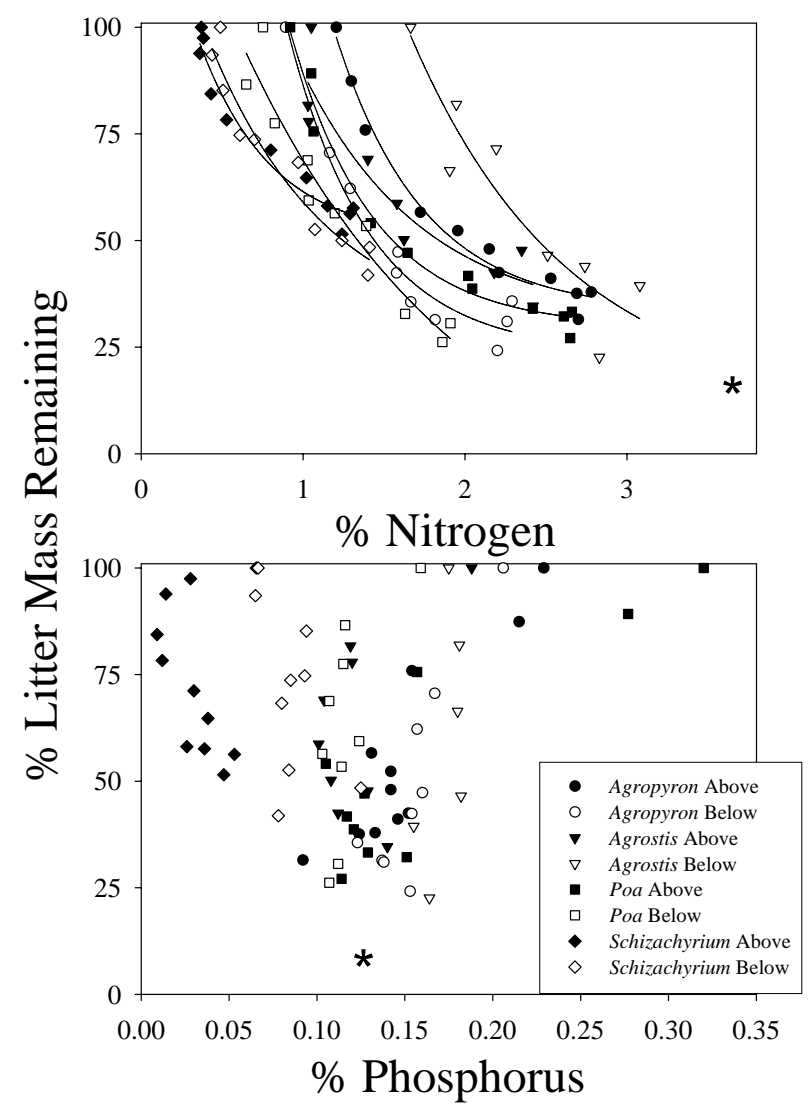

Fig. (4). Litter mass loss versus litter percent nitrogen, respectively litter percent phosphorus during decomposition in four grass species (e.g. Agrostis scabra, Agropyron repens, Poa pratensis and Schizachyrium scoparium). Data are from both above- and belowground tissues for each species. Litter was decomposed over a 3.5 year period and the data are the average of four litterbags per sampling period. $*$ denotes the $\%$ nitrogen and $\%$ phosphorus in soil organic matter. All data and methods can be found in Wedin et al. (1995).

\section{A NULL MODEL FOR DECOMPOSITION}

Based on these premises (Table 1), we can develop a basic model of litter decomposition (Fig. 6). In temperate terrestrial ecosystems, plants take up inorganic $\mathrm{N}$ and $\mathrm{P}$ and produce an annual flush of litter. These annual litter cohorts initiate a continuum by which SOM is formed. Litter cohorts and the final SOM can both immobilize or mineralize $\mathrm{N}$ and P (Fig. 6).

The mass loss of the litter can be fitted to a single exponential decay function with time as independent variable similarly to Olson (1963):

$x(t)=100 \cdot a \cdot \mathrm{e}^{-k . t}$

where $x(t)$ is the remaining mass at time $t, a$ is a constant, $k$ the relative rate of mass loss and $t$ is time (middle line in Fig. 7A). If we assume that $20 \%$ of the organic mass is turned into SOM at time step 10, we can estimate (a) as 14.67. 


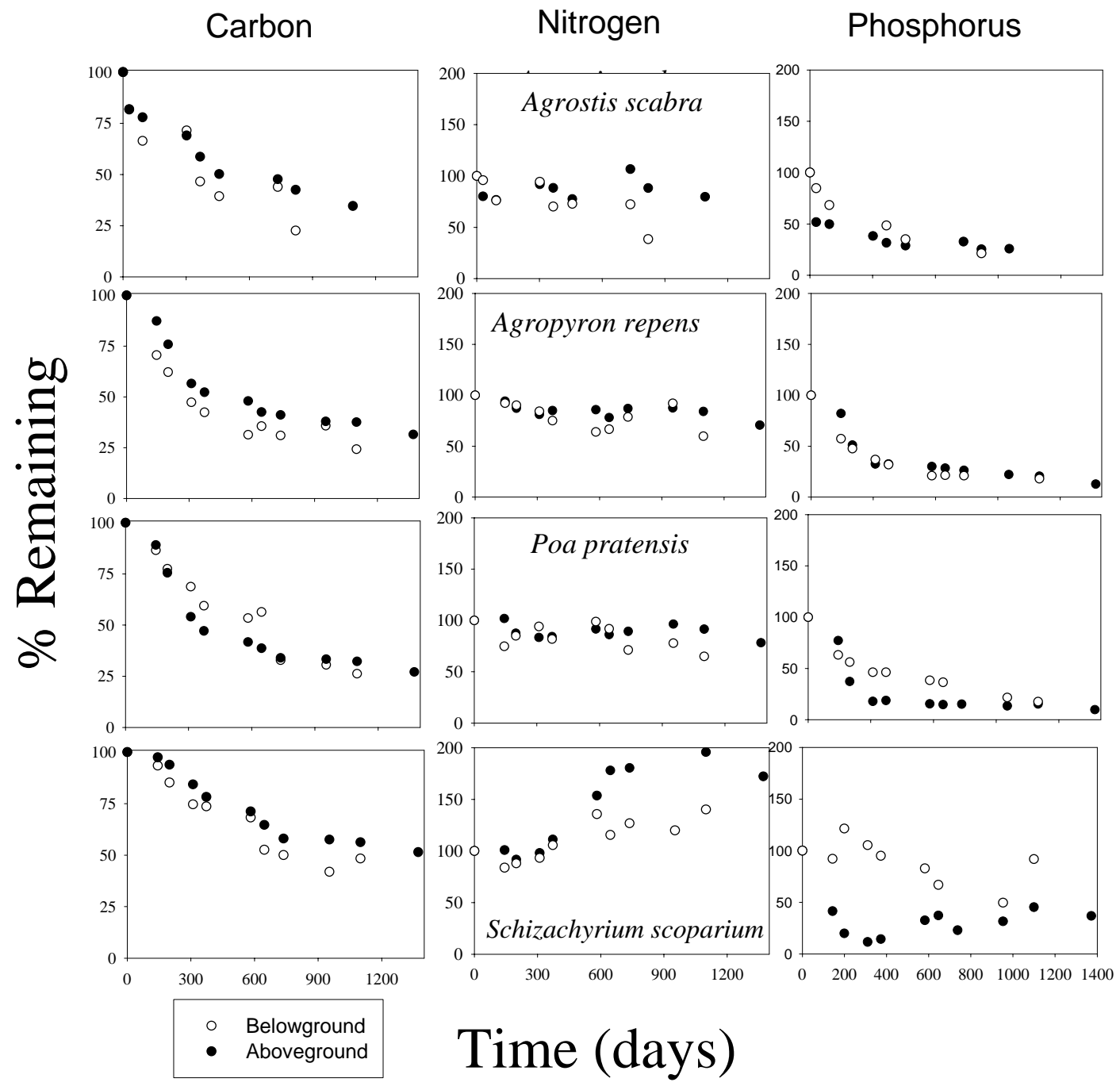

Fig. (5). Carbon, nitrogen and phosphorus remaining within decomposing litter over a two year period of aboveground (closed circles) and belowground (open circles) tissues of Agropyron repens, Agrostis scabra, Poa pratensis and Schizachyrium scoparium. Initial C, N and P are set to $100 \%$. All data are from Wedin et al. (1995).

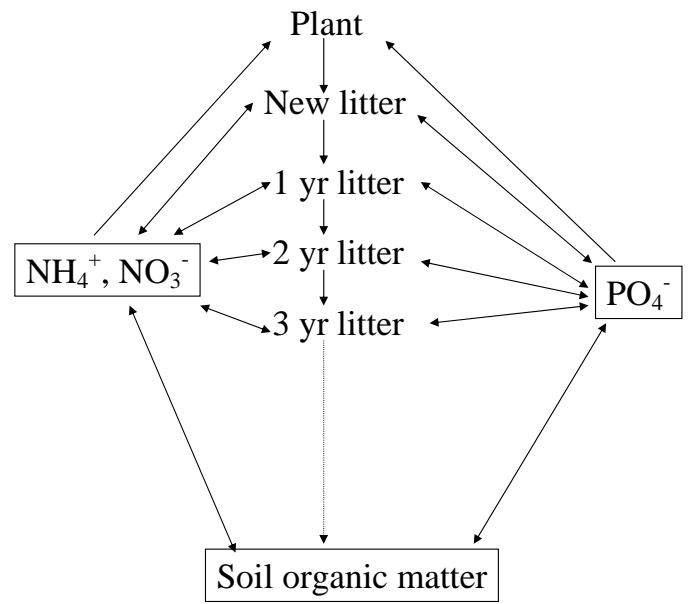

Fig. (6). The flows of nitrogen and phosphorus from the plant through annual litter cohorts into the soil organic matter. Note that litter and soil organic matter can both immobilize nitrogen and phosphorus.
Similarly, organic mass remaining as a function of litter $\mathrm{N}$ can be fitted with a single exponential decay function with time as the independent variable:

$O(t)=O(0) \cdot a \cdot \mathrm{e}^{-n . t}$

Where $O(t)$ is the remaining mass at time $t, a$ is a constant, $n$ the relative rate of $\mathrm{N}$ loss and $t$ is time (middle line in Fig. 7B). If we assume that $20 \%$ of the organic mass is turned into SOM at time step 10, that SOM contains $3.75 \% \mathrm{~N}$, and that initial litter percent $\mathrm{N}$ is 0.75 (middle line in Fig. 7B), we can estimate $O(0)$ as 15.80, $a$ as 178.29 and $n$ as 1.000 . Using these assumptions, we find that there is no net release of $\mathrm{N}$ from the litter during decomposition (middle line in Fig. 7C).

If we assume that SOM contains $0.1 \% \mathrm{P}$, the same as the $\mathrm{P}$ concentration in the litter, $\mathrm{P}$ concentration of the remaining litter does not change over time (middle line in Fig. 7D) and the $\mathrm{P}$ remaining in the litter follows the same function as mass loss (middle line in Fig. 7E). We find that $\mathrm{P}$ is mineralized and released from the litter during 


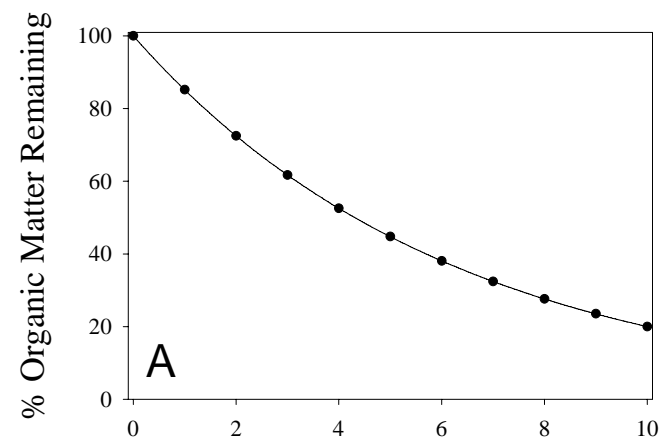

Time
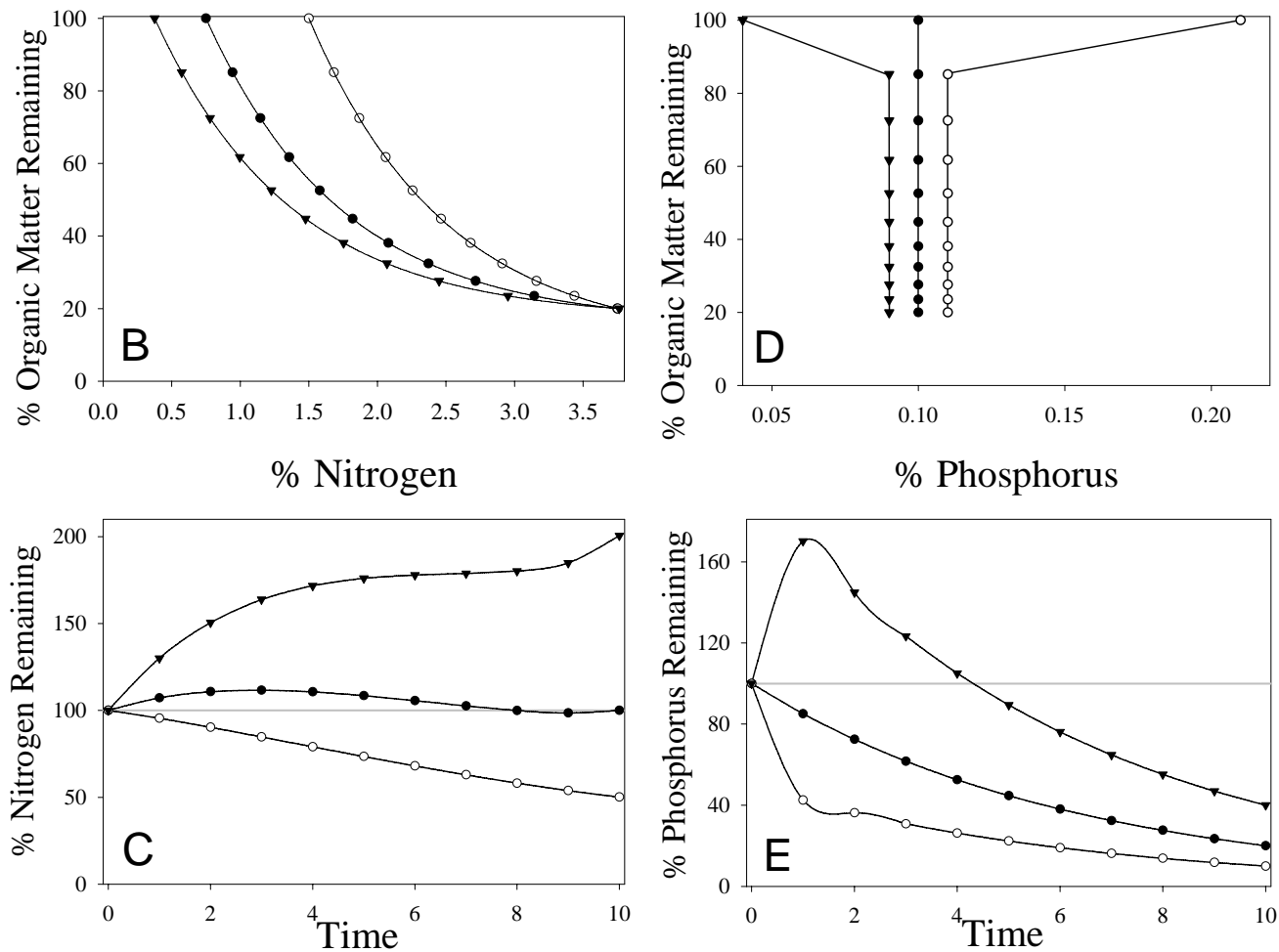

Fig. (7). The dynamics of mass loss, nitrogen and phosphorus during decomposition. The middle lines show the exponential decay of organic matter on a continuum from litter to soil organic matter with as assumptions $14.67 \%$ mass loss per time step, $20 \%$ mass remaining at time step 10 with $3.75 \%$ nitrogen and $0.1 \%$ phosphorus. A) mass loss, B) mass loss versus remaining nitrogen concentration, C) mass loss versus remaining phosphorus concentration, D) nitrogen retention during decomposition and $\mathbf{E}$ ) phosphorus retention during decomposition. The upper and lower lines simulate different litter qualities (see Table $\mathbf{1}$ for parameters). Note that the percent phosphorus is offset by 0.01 for clarification.

decomposition in direct proportion to mass loss of the decomposing litter (middle line in Fig. 7E). Thus, no net $\mathrm{N}$ is released from the litter during decomposition, which implies that either no $\mathrm{N}$ is released during decomposition or that immobilization equals mineralization. In contrast, for P the rate of decomposition directly controls the release of $\mathrm{P}$ (Fig. $7 \mathbf{E}$ ), because no immobilization occurs and all $\mathrm{P}$ is mineralization in direct proportion to mass loss of the litter.

We can use this model of decomposition to test how differences in initial litter quality and the amount of litter transformed into SOM affect the mineralization and immobilization of $\mathrm{N}$ and $\mathrm{P}$.

\section{MODEL SENSITIVITY SIMULATIONS}

\section{The Impact of Litter Quality; Model Predictions}

Our initial model assumes that fresh litter contains $0.75 \%$ $\mathrm{N}$ and $0.1 \% \mathrm{P}$. We tested the sensitivity of $\mathrm{N}$ and $\mathrm{P}$ dynamics by examining two changes; $1 / 2$ the amount of initial $\mathrm{N}$ or $\mathrm{P}$ present in the litter and twice the amount present (Table 1, Fig. 7B and D). This leads to a fourfold difference in longterm $\mathrm{N}$ and $\mathrm{P}$ release (Fig. $\mathbf{7 C}$ and $\mathbf{E}$ ). However, note that in all three scenarios, the majority of $\mathrm{P}$ present in the initial litter is released. In contrast, any decrease in initial litter $\mathrm{N}$ results in $\mathrm{N}$ immobilization, whereas any increase in litter $\mathrm{N}$ 
results in net $\mathrm{N}$ release. Secondly, there is a large difference in $\mathrm{P}$ release over the initial time step $(110 \%)$, whereas there is only a $50 \%$ difference in $\mathrm{N}$ release. These results show that initial differences in litter quality are reflected in much larger shifts between mineralization and immobilization for $\mathrm{P}$ cycling as compared to $\mathrm{N}$ cycling. This difference in response time also has the potential for much faster feedbacks for $\mathrm{P}$ as compared to $\mathrm{N}$, if primary productivity is constrained by nutrient availability. Differences between $\mathrm{P}$ and $\mathrm{N}$ are also likely to be enhanced by any litter quality impacts on the rate of decomposition, which impact $\mathrm{P}$ release more because of rapid divergence (Fig. 7E). Thus, litter quality differences are much more likely to lead to positive or negative feedbacks for $\mathrm{P}$ cycling than for $\mathrm{N}$ cycling. Some empirical studies support these model predictions (Silver, 1994, Knops et al., 1997, Knops and Koenig, 1997).

Decreases in litter quality result in much larger $\mathrm{N}$ immobilization as compared to the increased mineralization with increasing litter quality (e.g. decreasing litter $\mathrm{N}$ by $50 \%$ doubles the amount of $\mathrm{N}$ immobilized, whereas a doubling of initial $\mathrm{N}$ only releases $50 \%$ of the $\mathrm{N}$ present). Thus, any decrease in litter quality in plant communities will have much larger negative feedback than the positive feedback resulting from an increase in litter quality. Based on this, negative feedbacks are likely to be more important in structuring differences among and within ecosystem $\mathrm{N}$ cycling than positive feedbacks.

\section{Differences in the Efficiency by which Litter is Transformed into Soil Organic Matter}

Ecosystems may also differ in the fraction of the litter that becomes SOM (decomposition efficiency) because of differences in the physical environment (e.g. the percent clay present or climate). We simulated this by changing the proportion of litter stabilized as SOM to half or twice the amount of the null model (Table 1, Fig. 8A). Nitrogen release follows essentially the same long-term changes as shown for changes in litter quality (Figs. 7C, 8C). However, short-term $\mathrm{N}$ release changes are much smaller, i.e. $12 \%$ versus $50 \%$ as compared to the null model at timestep 1 . Thus, in the short-term, plant quality is more important than decomposition efficiency. However, long-term $\mathrm{N}$ release patterns, and thereby any positive or negative feedbacks on $\mathrm{N}$ cycling, are as much dependent on decomposition efficiency as they are on plant quality. In contrast, $\mathrm{P}$ release shows a markedly different release pathway (Fig. 8E). Differences in plant quality demonstrate that all three decomposition efficiency scenarios show an exponential release with the same long-term retention. In the short-term, however, plant quality matters much more, e.g. $110 \%$ versus $8 \%$ in $\mathrm{P}$ release as compared to the null model at timestep 1. Thus, again, long-term $\mathrm{P}$ cycling is determined as much by litter quality as decomposition efficiency. However, over the short term, any $\mathrm{P}$ cycling feedbacks depend much more on the litter quality than $\mathrm{N}$ cycling feedbacks.

Across broad climatic gradients from hot and dry to cool and moist there is a large increase in SOM and presumably the fraction of plant litter stabilized as SOM. The scenario in Fig. (8) represents such a gradient. Across this gradient the net release of $\mathrm{N}$ during litter decomposition (i.e. up to $20 \%$ initial mass remaining) decreases from $50 \%$ to zero release to high rates of immobilization. In contrast, more than $50 \%$ of plant litter $\mathrm{P}$ is mineralized during litter decomposition regardless of position along the gradient. Thus, ecosystem functioning differences across climatic gradients are predominantly determined by $\mathrm{N}$ cycling differences.

\section{Differences in Nitrogen and Phosphorus Concentration in Soil Organic Matter}

The C:N ratio of the SOM might also vary because of differences in SOM formed by different decomposer groups such as fungi or bacteria or because of soil texture and other site conditions. We simulated a change in the $\% \mathrm{~N}$ and $\mathrm{P}$ retained in the SOM by again using $1 / 2$ or twice the amount in the model (Table 1, Figs. 9B and D), and by keeping the proportion of litter stabilized as SOM constant (Fig. 9A).

Table 1. Model Assumptions and Sensitivity Analysis (See the section "Nitrogen and Phosphorus Mineralization" for the

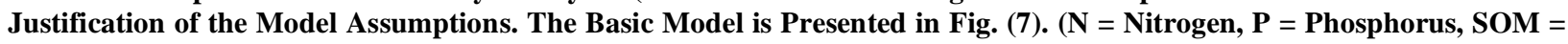
Soil Organic Matter)

\begin{tabular}{|c|c|c|}
\hline Decomposition Dynamics & Sensitivity Analysis & Figure \\
\hline \multicolumn{3}{|c|}{ The transformation of litter into SOM is best viewed as a continuum } \\
\hline \multicolumn{3}{|c|}{ Litter decomposition follows an exponential decay function } \\
\hline $20 \%$ of the litter is transformed into SOM & 10 and $40 \%$ & 8 \\
\hline \multicolumn{3}{|l|}{ Nitrogen dynamics } \\
\hline \multicolumn{3}{|c|}{$\% \mathrm{~N}$ increases exponentially from the initial litter $\%$ to the final SOM } \\
\hline$\% \mathrm{~N}$ of initial litter is 0.75 & 0.375 and $1.5 \%$ & 7 \\
\hline$\% \mathrm{~N}$ of the $\mathrm{SOM}$ is $3.75(\mathrm{C}: \mathrm{N} \mathrm{12})$ & 1.875 and $7.5 \%$ & 9 \\
\hline \multicolumn{3}{|l|}{ Phosphorus dynamics } \\
\hline \multicolumn{3}{|c|}{$\%$ P increases in the first time step from the initial litter $\%$ to the final SOM $\%$} \\
\hline$\% \mathrm{P}$ of initial litter is 0.1 & 0.05 and $0.2 \%$ & 7 \\
\hline$\% \mathrm{P}$ of the SOM is $0.1 \%(\mathrm{C}: \mathrm{N} 1000)$ & 0.05 and $0.2 \%$ & 9 \\
\hline
\end{tabular}




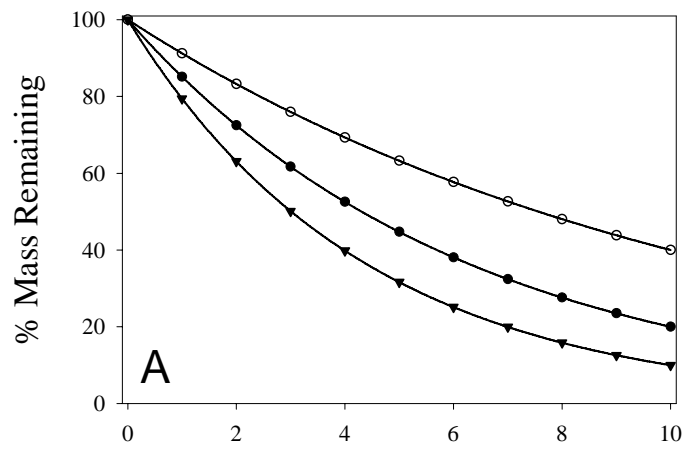

Time
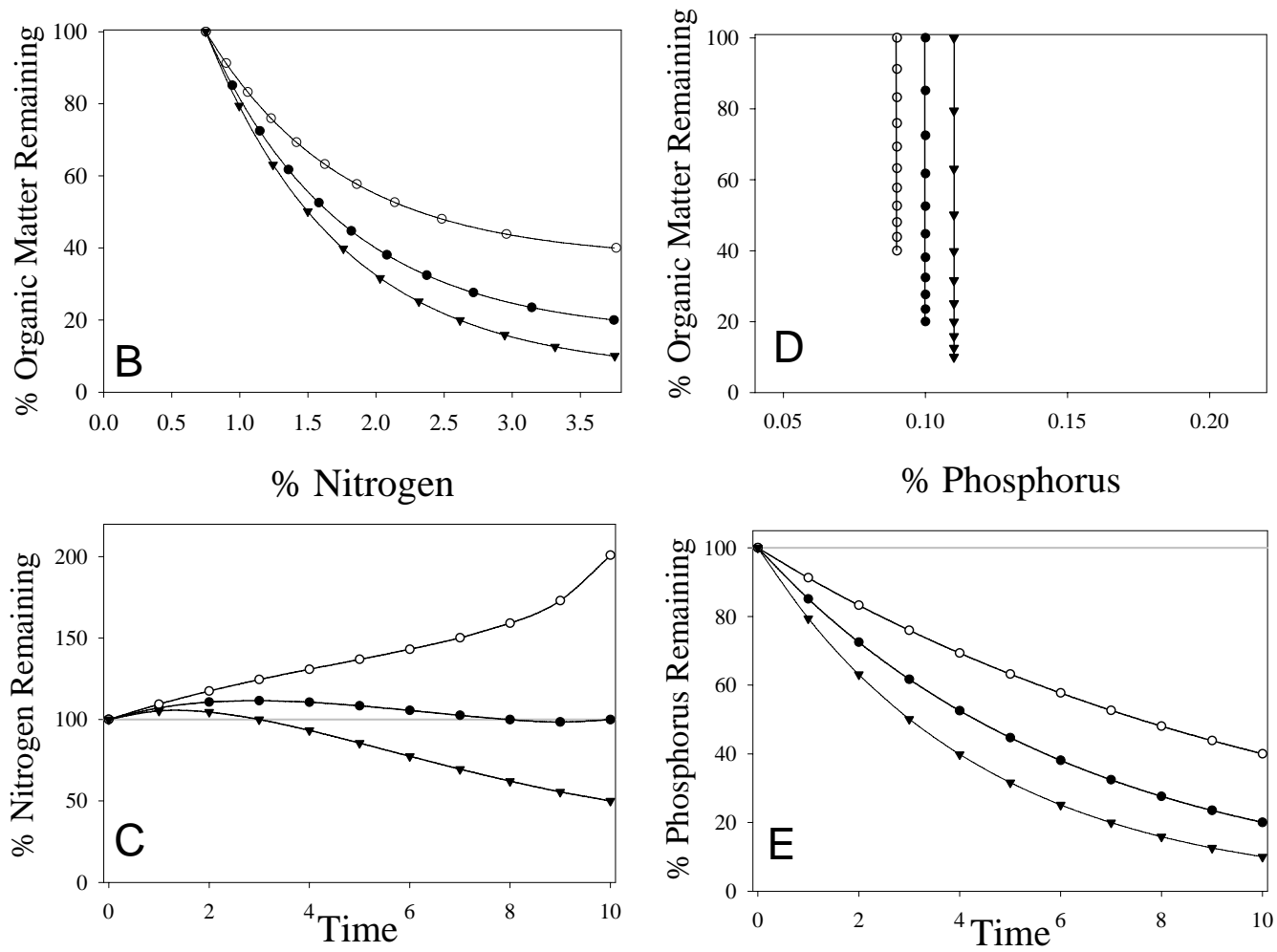

Fig. (8). Simulation of differences in the efficiency by which litter is transformed in soil organic matter (see Table $\mathbf{1}$ for parameters). A) mass loss, B) mass loss versus remaining nitrogen concentration, C) mass loss versus remaining phosphorus concentration, D) nitrogen retention during decomposition and $\mathbf{E}$ ) phosphorus retention during decomposition. Note that the percent phosphorus is offset by 0.01 for clarification.

Nitrogen showed the same long-term release pattern as shown for a change in litter quality and the decomposition efficiency (Figs. 7C, 8C, 9C). Note that the specific pattern of $\mathrm{N}$ immobilization at the doubling of the $\% \mathrm{~N}$ is driven by the assumptions of our model, e.g. a fixed percent of C loss for each time step. However, it is clear that the temporal dynamics of $\mathrm{N}$ release are distinctly different, with most of the immobilization occurring in the late decomposition stage. Phosphorus release showed the same pattern as it showed for changes in decomposer efficiency.

\section{DISCUSSION}

There are many other modeling approaches used to examine litter decomposition (Olson, 1963, Parnas, 1975,
Ågren and Bosatta, 1996, Bloemhof and Berendse, 1995). Our model closely parallels these models and, like other models, we used a first order decay function as originally developed by Olson (1963). Our study suggests that our relatively simple model is consistent with our understanding of ecosystem processes yet provides novel insights into the general properties of $\mathrm{N}$ and $\mathrm{P}$ cycling. Model predictions agree with data from grassland ecosystems that meet most of the assumptions of our model. This model, however, is not likely to hold for systems where inputs/outputs dominate nutrient cycling, such as streams and wetlands, and systems where decomposition is strongly limited, such as peat bogs. Ecosystems where the dominant pool of nutrients is within the vegetation and not in the litter and soil compartment, such as tropical forests, and ecosystems where fire (Ojima $e t$ 

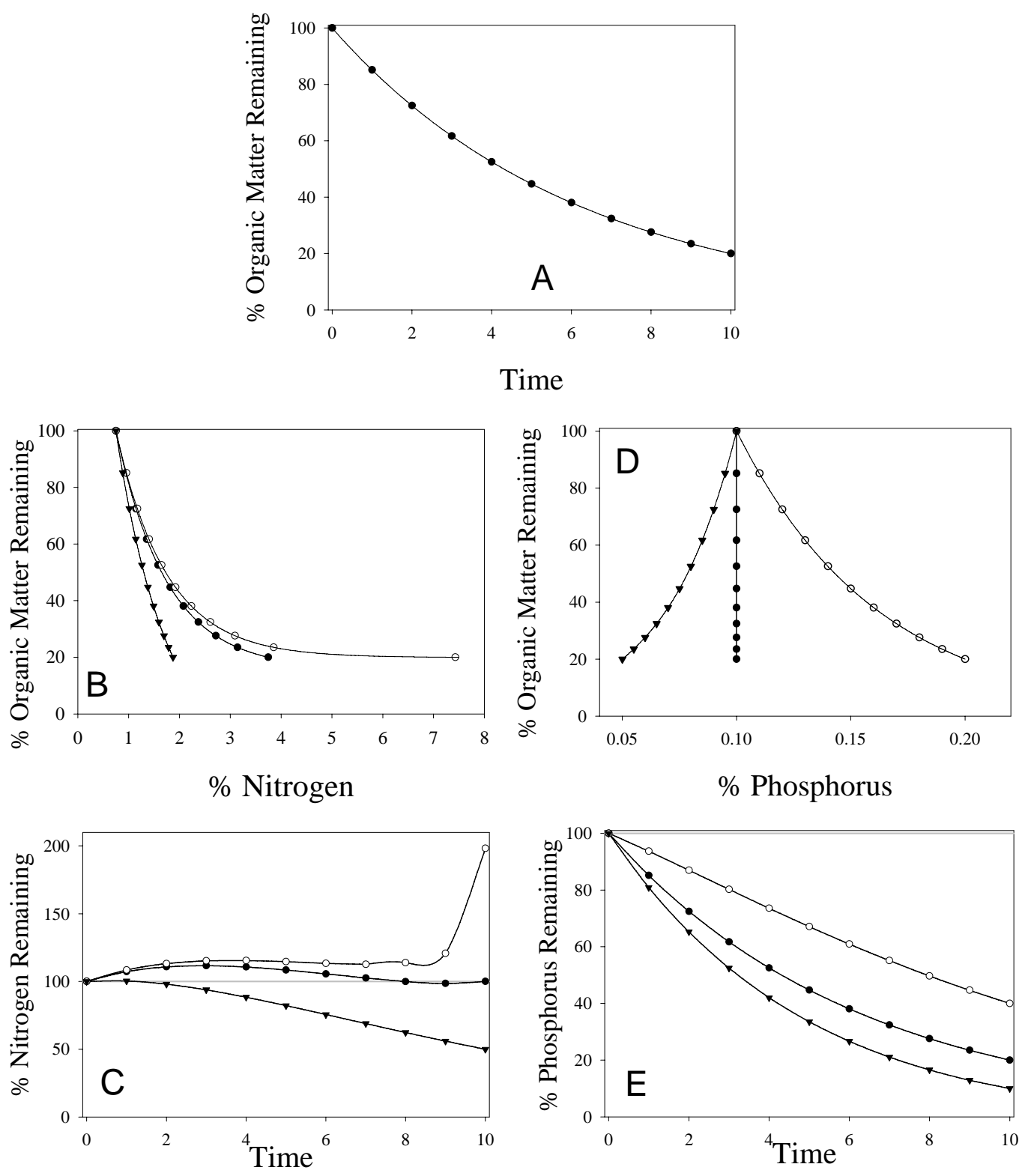

Fig. (9). Simulation of differences in nitrogen and phosphorus concentration of the soil organic matter (see Table 1 for parameters). A) mass loss, B) mass loss versus remaining nitrogen concentration, C) mass loss versus remaining phosphorus concentration, D) nitrogen retention during decomposition and $\mathbf{E}$ ) phosphorus retention during decomposition.

al., 1994, Reich et al., 2001) or UV light (Parton et al., 2007) are important also will not have the bottleneck of nutrient accumulation within the soil compartment, which is the most important feature of this model. Nevertheless, this model might also be useful in ecosystems where it does not capture the essence of nutrient cycling, because it allows us to examine which of the premises underlying the model (Table 1) is invalid. By using this model as a null model, we might gain insights in the factors that are causing differences in nutrient cycling among ecosystems.

Many studies have shown that there is a dynamic turnover of $\mathrm{N}$ within decomposing litter caused by microbial uptake of $\mathrm{N}$ from litter followed by the incorporation of this
$\mathrm{N}$ into microbial tissues which are then incorporated as dead microbial biomass into litter (Berg, 1988, Blair et al., 1992). In addition, there is increasing evidence that plants can assimilate organic $\mathrm{N}$ and that net $\mathrm{N}$ mineralization does not always reflect plant available $\mathrm{N}$ (Schimel and Bennett, 2004). However, neither the dynamic nature of $\mathrm{N}$ within the litter nor the uptake of organic $\mathrm{N}$ diminishes the importance of net $\mathrm{N}$ mineralization and immobilization, because these net fluxes determine any potential feedbacks through nutrient cycling.

We predict that $\mathrm{N}$ release during litter decomposition becomes more important with higher litter quality, decreasing soil $\mathrm{C}: \mathrm{N}$ ratios and decreased SOM stabilization 
(i.e. warm temperatures, low clay content, increased soil disturbance). The relative importance of these factors appears to be similar. Studies have shown that the long-term $\mathrm{N}$ release patterns are dependent on litter quality (Parton et al., 2007) and decomposer efficiency (Manzoni et al., 2008). However, this study shows that $\mathrm{N}$ release patterns are as much dependent on litter quality as on decomposition efficiency and the $\mathrm{N}$ concentration present in SOM, whereas short-term release patterns show a greater sensitivity to litter quality. In all these scenarios, at least $50 \%$ of the $\mathrm{N}$ present in the litter is retained within the SOM, and the magnitude of difference in release patterns is in the order of $150 \%$ of the initial $\mathrm{N}$ present in the litter. Thus, $\mathrm{N}$ cycling is structured much more by immobilization than mineralization. In contrast, $\mathrm{P}$ release patterns are dominated by $\mathrm{P}$ mineralization in proportion to litter mass loss, and the majority is mineralized in all three scenarios showing no more than $30 \%$ difference. Short-term $P$ release patterns depend primarily on changes in litter quality, whereas $\mathrm{N}$ release patterns do not. Long-term $\mathrm{N}$ cycling can vary widely based on difference in litter quality, decomposition efficiency and the SOM C:N ratio, whereas $\mathrm{P}$ cycling varies much less.

The direct impacts of litter quality on nutrient cycling are expected to be larger and faster for $\mathrm{P}$ than for $\mathrm{N}$. Our simple model suggests that the dynamics of $\mathrm{P}$ release during the early stages of decomposition appear to be much more dependent on litter quality than the short-term dynamics observed for $\mathrm{N}$. Thus, $\mathrm{P}$ has a much larger potential for short-term positive and negative litter quality feedbacks than $\mathrm{N}$ cycling. This difference between $\mathrm{N}$ and $\mathrm{P}$ might explain why Scott and Binkley (1997) and Knops et al. (1997) did not find any relationship between litterfall $\mathrm{N}$ concentration and N mineralization, whereas Silver (1994) did find a significant relationship for P. As our study indicates, rates of long-term $\mathrm{N}$ cycling will diverge much more than short term cycling among ecosystems that differ in litter quality, decomposition efficiency and the nature of the SOM. Thus it is not surprising that results from different sites may disagree with one another when such properties vary among sites.

A key factor in determining feedbacks in ecosystem $\mathrm{N}$ cycling is the degree to which ecosystem $\mathrm{N}$ cycling is closed (Tateno and Chapin, 1997, Knops et al., 2002). Species changes in plant community composition that alter $\mathrm{N}$ inputs or losses have the potential to drastically alter feedbacks (de Mazancourt et al., 1998, 1999, de Mazancourt and Loreau, 2000). Closed ecosystems have a negative feedback by which increased productivity leads to high $\mathrm{C}: \mathrm{N}$ ratios, low decomposition, reduced $\mathrm{N}$ mineralization and subsequently decreases in productivity (Tateno and Chapin, 1997). This feedback is reflected in our basic model, where $\mathrm{N}$ content of the litter increases during decomposition and differences in initial plant material have a positive or negative feedback through $\mathrm{N}$ release. Our study suggests that decomposer efficiency and $\mathrm{N}$ concentration in SOM have as much impact on these feedbacks as initial plant quality. Furthermore our study suggests that negative feedbacks are likely to be more important than positive feedbacks.

In total, $\mathrm{P}$ release during litter decomposition plays a dominant role in $\mathrm{P}$ cycling and $\mathrm{P}$ cycling feedbacks are for a large part controlled by litter quality differences. The same cannot be said for $\mathrm{N}$. The majority of $\mathrm{N}$ in all our modeling scenarios, as well as the empirical data we present becomes stabilized as SOM. This leads to a time lag in any potential litter quality impact on $\mathrm{N}$ cycling and the potential for $\mathrm{N}$ cycling feedbacks is much lower than for P. We suggest that the emphasis in terrestrial grassland ecosystem literature on the role of litter quality feedbacks to explain $\mathrm{N}$ cycling reflects an incomplete picture of the process. The mineralization of SOM is the key area that we need to focus on to develop a better understand of $\mathrm{N}$ cycling.

\section{ACKNOWLEDGEMENTS}

We thank Tamara Kaup for discussions and comments. This study was supported by the National Science Foundation.

\section{REFERENCES}

Aerts, R, Wallen, B, \& Malmer, N (1992) Growth-limiting nutrients in Sphagnum-dominated bogs subject to low and high atmospheric nitrogen supply. Journal of Ecology, 80, 131-40.

Ågren, GI, \& Bosatta, E (1996) Theoretical Ecosystem Ecology. Understanding Element Cycles, Cambridge: Cambridge University Press.

Attiwill, PM \& Adams, MA (1993) Nutrient cycling in forests. New Phytologist, 124, 561-82.

Berendse, F, Berg, B, \& Bosatta, E (1987) The effect of lignin and nitrogen on the decomposition of litter in nutrient-poor ecosystems: a theoretical approach. Canadian Journal of Botany, 65, 1116-20.

Berg, B (1988) Dynamics of nitrogen (15N) in decomposing Scots pine (Pinus sylvestris) needle litter. Long-term decomposition in a Scots pine forest. VI. Canadian Journal of Botany, 66, 1539-46.

Berg, B, \& Ågren, GI (1984) Decomposition of needle litter and its organic chemical components. - Theory and field experiments. Long-term decomposition in a Scots pine forest. III. Canadian Journal of Botany, 62, 2880-88.

Berg, B, Hannus, K, Popoff, T \& Theander, O (1982) Changes in organic chemical components of needle litter during decomposition. I. Long term decomposition in a Scotts pine forest. Canadian Journal of Botany, 60, 1310-19.

Blair, JM, Crossley, DA \& Callaham, LC (1992) Effects of litter quality and microarthopods on $\mathrm{N}$ dynamics and retention of exogenous $15 \mathrm{~N}$ in decomposing litter. Biology and Fertility of Soils, 12, 241-52.

Bloemhof, HS \& Berendse, F (1995) Simulation of the decomposition and nitrogen mineralization of aboveground plant material in two unfertilized grassland ecosystems. Plant and Soil, 177, 157-73.

Brady, NC \& Weil, RR (1999) The Nature and Properties of Soils. $12^{\text {th }} \mathrm{ed}$, Upper Saddle River, NJ: Prentice Hall.

Cole, DW \& Rapp, M (1981) Elemental cycling in forest ecosystems. In Reichle, D.E. (Ed.) Dynamic properties of forest ecosystems. London, International Biological Programme 23. Cambridge University Press.

Coyne, M (1999) Soil Microbiology: An Exporatory Approach, Albany: Delmar Publishers.

Crews, TE (1993) Phosphorus regulation of nitrogen fixation in a traditional Mexican agroecosystem. Biogeochemistry, 21, 141-66.

Cross, AF \& Schlesinger, WH (1995) A literature review and evaluation of the Hedley fractionation: Applications to the biogeochemical cycle of soil phosphorus in natural ecosystems. Geoderma, 64, 197-214.

De Mazancourt, C \& Loreau, M (2000) Effect of herbivory and plant species replacement on primary production. American Naturalist, $155,735-54$.

De Mazancourt, C, Loreau, M, \& Abbadie, L (1998) Grazing optimization and nutrient cycling: when do herbivores enhance plant production? Ecology, 79, 2242-52. 
De Mazancourt, C, Loreau, M \& Abbdie, L (1999) Grazing optimization and nutrient cycling: potential impact of large herbivores in a savanna system. Ecological Applications, 9, 784-97.

Eason, WR \& Newman, EI (1990) Rapid cycling of nitrogen and phosphorus from dying roots of Lolium perenne. Oecologia, 82, 432-36.

Fog, K (1988) The effect of added nitrogen on the rates of decomposition of organic matter. Biological Review, 63, 201-35.

Frank, DA, Inouye, RS, Huntley, N, Minshall, GW \& Anderson, JE (1994) The biogeochemistry of a north-temperate grassland with native ungulates: Nitrogen dynamics in Yellowstone National Park. Biogeochemistry, 26, 163-88.

Goble, RJ, Mason, JA, Loope, DB \& Swinheart, JB (2002) Optically stimulated luminescence and radiocarbon ages of stacked paleosols and dune sands in the Nebraska Sand Hills, USA. Quaternary Research, submitted.

Harte, J \& Kinzig, AP (1993) Mutualism and competition between plants and decomposers: implications for nutrient allocation in ecosystems. American Naturalist, 141, 829-46.

Hobbie, S (1992) Effects of plant species on nutrient cycling. Trends in Ecology and Evolution, 7, 336-39.

Hobbie, SE (1996) Temperature and plant species control over litter decomposition in Alaskan tundra. Ecological Monographs, 66, 503-22.

Hollinger, DY (1986) Herbivory and the cycling of nitrogen and phosphorus in isolated California oak trees. Oecologia, 70, 291-97.

Jenkinson, DS \& Rayner, JH (1977) The turnover of soil organic matter in some of the Rothamsted classical experiments. Soil Science, 123, 298-305.

Jobbagy, EG \& Jackson, RB (2001) The distribution of soil nutrients with depth: global patterns and the imprint of plants. Biogeochemistry, 53, 51-77.

Knops, JMH (1994) The influence of epiphytic lichens on the nutrient cycling of an oak woodland. Tempe: Arizona State University; 146, $\mathrm{PhD}$ dissertation.

Knops, JMH \& Bradley, KL (2009) Soil carbon and nitrogen accumulation and vertical distribution across a 74-year chronosequence. Soil Science Society of America Journal, 73, 2096-2104.

Knops, JMH Bradley, KL \& Wedin, DA (2002) Mechanisms of plant species impacts on ecosystem nitrogen cycling. Ecology Letters, 5, 454-66.

Knops, JMH \& Koenig, WD (1997) Site fertility and leaf nutrients of sympatric evergreen and deciduous species of Quercus in central coastal California. Plant Ecology, 130, 121-31.

Knops, JMH, Koenig, WD \& Nash III, TH (1997) On the relationship between nutrient use efficiency and fertility in forest ecosystems. Oecologia, 110, 550-56.

Knops, JMH, Nash III, TH \& Schlesinger, WH (1996) The influence of epiphytic lichens on the nutrient cycling of an oak woodland. Ecological Monographs, 66, 159-80.

Knops, JMH, Ritchie, M \& Tilman, D (2000) The effect of selective herbivory on a nitrogen fixing legume (Lathyrus venosus) on productivity and ecosystem nitrogen pools of an oak savanna. Ecoscience, 7, 166-74.

Likens, GE, Bormann, FH, Pierce, RS, Eaton, JS \& Johnson, NM (1977) Biochemistry of a Forested Ecosystem, New York: Springer Verlag.

Manzoni, S, Jackson, RB, Trofymow, JA \& Porporato, A (2008) The global stoichiometry of litter nitrogen mineralization. Science, 321, 68486.

Mcgill, FW \& Cole, CV (1981) Comparative aspects of cycling of organic C, N, S and P through soil organic matter. Geoderma, 26, 267-86.

Melillio, JM, Aber, JD, Linkins, AE, Ricca, A, Fry, B \& Nadelhoffer, KJ (1989) Carbon and nitrogen dynamics along a decay continuum: plant litter to soil organic matter. Plant and Soil, 115, 189-98.

Ojima, DS, Schimel, DS, Parton, WJ \& Owensby, CE (1994) Long- and short-term effects of fire on nitrogen cycling in tallgrass prairie. Biogeochemistry, 24, 67-84.

Olson, JS (1963) Energy storage and the balance of producers and decomposers in ecological systems. Ecology, 44, 322-31.
Parnas, H (1975) Model for decomposition of organic matterial by microorganisms. Soil Biology and Biochemistry, 7, 161-69.

Parton, W, Silver WL, Burke, IC, Grassens, L, Harmon, ME, Currie, WS, King, JY, Adair, EC, Brandt, LA, Hart, SC \& Fasth, B (2007) Global-scale similarities in nitrogen release patterns during longterm decomposition. Science, 315, 361-64.

Pastor, J \& Bockheim, JG (1984) Distribution and cycling of nutrients in an Aspen-mixed-hardwood-spodosol ecosystem in Northern Wisconsin. Ecology, 65(2), 339-53.

Post, WM, Pastor, J, Zinke, PJ \& Stangenberger, AG (1985) Global patterns of soil nitrogen storage. Nature, 317, 613-16.

Reich, PB, Peterson, DW, Wedin, DA \& Wrage, K (2001) Fire and vegetation effects on productivity and nitrogen cycling across a forest-grassland continuum. Ecology, 82, 1703-1719.

Ritchie, ME \& Tilman, D (1995) Responses of legumes to herbivores and nutrients during succession on a nitrogen-poor soil. Ecology, 76, 2648-55.

Schimel, JP \& Bennett, J (2004) Nitrogen mineralization: Challenges of a changing paradigm. Ecology, 591-602.

Schiesinger, WH (1997) Biogeochemistry. An Analysis of Global Change. $2^{\text {nd }}$ ed, San Diego: Academic Press.

Schulten, HR \& Schnitzer, M (1998) The chemistry of soil organic nitrogen: a review. Biology and Fertility of Soils, 26, 1-15.

Scott, NA \& Binkley, D (1997) Foliage litter quality and annual net N mineralization: comparison across North American forest sites. Oecologia, 111, 151-59.

Silver, WL (1994) Is nutrient availability related to plant nutrient use in humid tropical forests? Oecologia, 98, 336-43.

Smith VH (1992) Effects of nitrogen:phosphorus supply ratios on nitrogen fixation in agricultural and pastoral ecosystems. Biogeochemistry, 18, 19-35.

Sowden, FJ, Chen, Y \& Schulten, M (1977) The nitrogen distribution in soils formed under widely different climatic conditions. Geochimica et Cosmochimica Acta, 41, 1524-26.

Stinner, BR, Crossley, DA, Odum, EP \& Todd, RL (1984) Nutrient budgets and internal cycling of $\mathrm{N}, \mathrm{P}, \mathrm{K}, \mathrm{Ca}$ and $\mathrm{Mg}$ in conventional tillage, no-tillage, and old-field ecosystems on the Georgia Piedmont. Ecology, 65(2), 354-69.

Tateno, M \& Chapin III, FS (1997) The logic of carbon and nitrogen interactions in terrestrial ecosystems. American Naturalist, 149 , 723-44.

Tilman, D \& Wedin, D (1991) Plant traits and resource reduction for five grasses growing on a nitrogen gradient. Ecology, 72, 685-700.

Vitousek, PM (1984) Litterfall, nutrient cycling, and nutrient limitation in tropical forests. Ecology, 65, 285-98.

Vitousek, PM, Cassman, K, Cleveland, C, Crews, T, Field, CB, Grimm, NB, Howarth, RW, Marino, R, Martinelli, L, Rastetter, EB \& Spernt, JI. (2000) Towards an ecological understanding of biological nitrogen fixation. Biogeochemistry, 1-45.

Vitousek, PM \& Howarth, RW (1991) Nitrogen limitation on land and in the sea - How can it occur? Biogeochemistry, 13, 87-115.

Vitousek, PM \& Walker, LR (1989) Biological invasion by Myrica faya in Hawai'i: Plant demography, nitrogen fixation, ecosystem effects. Ecological Monographs, 59, 247-65.

Wadman, WP \& De Haans S (1996) Decomposition of organic matter from 36 soils in a long-term pot experiment. Plant and Soil, 189, 289301.

Waksman, SA (1924) Influence of microorganisms upon the carbon:nitrogen ratio in the soil. Journal of Agricultural Science, $14,555-62$.

Walker, TW \& Syers, JK (1976) The fate of phosphorus during pedogenesis. Geoderma, 15, 1-19.

Waring, RH \& Schlesinger, WH (1985) Forest Ecosystems. Concepts and Management, San Diego: Academic Press.

Wedin, DA \& Pastor, J (1993) Nitrogen mineralization dynamics in grass monocultures. Oecologia, 96, 186-92.

Wedin, DA, Tieszen, LL, Deway, B \& Pastor, J (1995) Carbon isotope dynamics during grass decomposition and soil organic matter formation. Ecology, 76, 1383-92.

Wedin, DA \& Tilman, D (1990) Species effect on nitrogen cycle: a test with perennial grasses. Oecologia, 84, 433-41. 
Zak, DR, Groffman, PM, Presgitzer, KS, Christensen, S \& Tiedje, JM (1990) The vernal dam: plant-microbe competition for nitrogen in

northern hardwood forests. Ecology, 71(2), 651-56.

Received: December 07, 2009

Revised: January 21, 2010

Accepted: January 22, 2010

(C) J.H.M Knops; Licensee Bentham Open.

This is an open access article licensed under the terms of the Creative Commons Attribution Non-Commercial License (http://creativecommons.org/licenses/bync/3.0/), which permits unrestricted, non-commercial use, distribution \& reproduction in any medium, provided the work is properly cited. 